\title{
On Reduction in English: What the English Don't Say
}

\begin{abstract}
The aim of this article is to examine which sounds are most often omitted in official oral public performances by native speakers of British English. Such terms as reduction, elision (and its types), and connected speech are explained; the literature cited is concerned with elision of vowels (triphthong smoothing being treated separately), of consonants, and of whole syllables. The study presents the results of an analysis conducted on selected material available on the Internet - this comprises three British English oral performances of the total length of approximately 20 minutes. With regard to the nature of the data, they were divided into scripted, semi-scripted, and unscripted samples. The research has shown that earlier preparation significantly lowers the number of phonetic reduction phenomena. Furthermore, if the speech is given in front of an audience rather than being pre-recorded, the number of reduction phenomena is higher. Besides, the analysis has shown a few important tendencies in modern British pronunciation, such as omission of / $t$ /, realisation of final / $t /$ as [?], omission of final / $t$ / in contractions, which therefore are realised as [n] instead of [nt].
\end{abstract}

Keywords: reduction, elision, connected speech, British English, oral performace

\section{Reduction, elision, and clipping}

In order to specify the topic of the article, ${ }^{1}$ let us consider two meanings of reduction:

reduce (v.) (1) A term used in the phonological classification of vowel sounds, referring to a vowel which can be analysed as a centralized variant of a vowel in a related form. For

1 The article is based on the author's BA thesis in English Philology at the Pedagogical University of Cracow, written under the supervision of Anita Buczek-Zawiła, Ph.D. 
example, the pronunciation of $/ \mathrm{pv} /$ reduces to /ov/ when unstressed; the stressed vowels in 'telegraph show reduction in the related word te'legraphy /'telagra:f/ $\Rightarrow /$ ta'legrafi/.

(2) A further phonological use of the term is found in the context of phonological rules, where it refers to a process of simplification which affects certain types of sound sequence. The most important category is consonant cluster reduction (e.g. clock becoming/gok/), which is common in early child language (Crystal 2008, 406).

In this paper, the focus is on the second meaning, whereby reduction is understood as elision. In phonology, elision, as defined by Crystal $(2008,166)$, is "the omission of sound or sounds in connected speech". ${ }^{2}$ It may affect vowels, consonants and even whole syllables. Elision may be further divided according to the position of the affected element (Skandera and Burleigh 2005, 96-97):

- aphaeresis: elision of an initial element or elements (would have [wəd 'æv]); if the initial omitted element is a vowel, the process can be named aphesis;

- syncope: elision of a medial element or elements (answer is ['a:ns. Iz]);

- apocope: elision of a final element or elements (kept complaining ['kep kəm' pleinin]).

However, if a part of a word or a whole syllable is omitted, we speak of clipping. Skandera and Burleigh $(2005,97)$, for instance, distinguish three types of clipping:

- fore-clipping: affects the initial part of a word, e.g. telephone-phone;

- back-clipping: affects the final part of a word, e.g. laboratory - lab;

- fore-and-aft clipping: fore- and back-clipping operate simultaneously, e.g. influenza - flu or Elizabeth - Liz.

In fore- and back-clipping, we understand the beginning and the end of a word in terms of its morphological borders.

Since vowel reduction (i.e. reduction in the first meaning) is not the subject of this paper, this change in grammatical words ${ }^{3}$ is not going to be considered. ${ }^{4}$ However, every non-standard pronunciation of these words will be noted and counted if affected by elision. What will not be counted are contracted forms, which are also treated as reduction, but counting them would be pointless because they are normative.

2 Connected speech is understood here as a continuous sequence of words typical of natural utterances and conversations. Units (words or phrases) sound different when they are pronounced in connected speech or in isolation. Another important process operating in connected speech, apart from elision, is assimilation (cf. Crystal 2008, 101).

3 That is, strong and weak forms of auxiliary verbs, conjunctions, prepositions, pronouns, articles etc.

4 Cf. Reszkiewicz (1981, 139-152) or Cruttenden (2008, 266-268). 


\section{Elision in the literature}

Elision, as understood in this article, has been the subject of numerous studies. It is usually divided into elision of vowels, consonants, and whole syllables. Within elision of vowels, triphthong smoothing can also be identified. All these will be described below.

\subsection{Elision of vowels}

The vowel schwa, transcribed /ə/, is commonly elided after voiceless plosives, namely $/ \mathrm{p} /, / \mathrm{t} /$ and $/ \mathrm{k} /$, in the direct vicinity of a stressed syllable. The loss of the vowel is therefore compensated by aspiration, e.g. potato /pə'teitəv/ $\rightarrow$ ['p $\mathrm{p}^{\text {htertəv}], ~ t o m a t o ~}$ $/$ tə'ma:təo/ $\rightarrow$ ['thma:təv $]$ or canal $/ \mathrm{kə}$ 'næl $/ \rightarrow\left[\mathrm{k}^{\mathrm{h}}\right.$ næł $]$. In such position, schwa is also often dropped when it precedes $/ \mathrm{n} /, / 1 /$ or $/ \mathrm{r} /$, which in this case become syllabic, as in police /pə'li:s/ $\rightarrow$ [pl'i:s], tonight /to'nart/ $\rightarrow$ [tn' ait] or correct /kə'.rekt/ $\rightarrow$ [kı' ekt]. Notice that in such cases, the boundaries of syllables also change (Skandera and Burleigh 2005, 95-96, Roach 1998, 127).

Cruttenden $(2008,303)$ points out that /a/ is often not pronounced at word boundaries when it is initial but preceded by a consonant and followed by a continuant. The

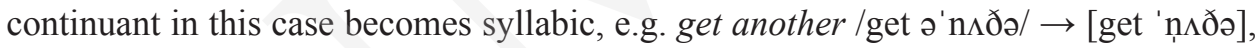

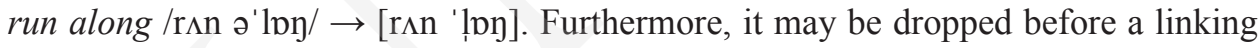
/r/, for example after a while /a:ftəı ə'waıl/ $\rightarrow$ [a:ftıə 'waił] or father and son /fa:ðəı ənd' $\mathrm{s} \Lambda \mathrm{n} / \rightarrow$ [fa:ðıən 's $\Lambda \mathrm{n}]$ (ibid).

\subsection{Triphthong smoothing}

Although triphthong smoothing is also an instance of vowel elision, it has been treated separately, because it affects a discrete category of sounds in English phonetics and phonology, namely triphthongs. These also undergo elision, or to be precise - syncope, which is an omission of the medial element of a triphthong $(/ \mathrm{I} /$ or $/ \mathrm{\mho} /)$, especially when the following /o/ is not a separate morpheme. Thus, triphthongs undergo following changes, which are known as smoothing (Cruttenden 2008, 145-146):

- /aiə/ $\Rightarrow[\mathrm{a}: 2]$ - in words such as tyre, wire, fire, but also in those where $/ 2 /$ is a suffix, such as buyer, higher or liar;

- /avə/ $\Rightarrow[\mathrm{a}: 2]$ - in shower or tower. Note that tyre and tower, shire and shower or buyer and bower become homophones when the smoothing occurs;

- /eıə/ $\Rightarrow[\mathrm{e}: 2]$ - as in player, prayer or layer. As we see, the smoothing may take place at morpheme boundaries as well, thus producing homophones, e.g. prayer (the words or the act of praying) and pray-er (a person who prays) or layer and lair;

- /əvə/ $\Rightarrow$ [3:] - as in mower or slower, which results in homophones with myrrh or slur, respectively;

- /ог/ $\Rightarrow[0$ :ə] - as in employer, joyous or enjoyable. Note, however, that the first element of the reduced diphthong, namely [ơ:], is lower than phonemic / $/ 2 /$. 
Moreover, triphthong smoothing occurs not only within one morpheme, but also at a morpheme boundary when word-initial / $/$ / comes after a closing diphthong at the end of a word, for instance in they are [ðe:ə], go away [gз:ə'wer], buy a house [ba:ə'haus], now and then [na:ən'ðen] or boy and girl [bọ:ən'gs:1] (Cruttenden 2008, 147).

\subsection{Elision of consonants and syllables}

The main factor triggering consonant elision is complex consonant clusters. The sounds that are most frequently omitted are plosives and fricatives. Skandera and Burleigh $(2005,95)$ provide such examples as clothes /kləoðz/ $\rightarrow$ [kləoz], months $/ \mathrm{m} \wedge \mathrm{n} \theta \mathrm{s} / \rightarrow$ [mıns] or twelfth /twelf $/ \rightarrow$ [twel $\theta]$.

As we read in Roach $(1998,127)$, the middle plosive is usually dropped in a cluster of two plosives and a fricative or of three plosives, which can be illustrated with such examples as acts /ækts/ $\rightarrow$ [æks], looked back/lokt 'bæk/ $\rightarrow$ [lok 'bæk].

Cruttenden $(2008,303)$ lists also even more complex clusters: "Thus elision is common in the sequence voiceless continuant $+/ \mathrm{t} /$ or voiced continuant $+/ \mathrm{d} /(\ldots)$ followed by a word with an initial consonant," which is exemplified by such phrases as next day [neks 'deI], raced back [.reIs 'bæk], last chance [la:s 'tfa:ns], left turn [lef 't3:n], send round [sen 'taond] or caused losses [ko:z 'lpsiz]. Further on, we read: "Similarly, word-final clusters of voiceless plosive or affricate $+/ t /$ or voiced plosive or affricate $+/ \mathrm{d} /(\ldots)$ may lose the final alveolar stop when the following word has an initial consonant," which is again illustrated with such examples as kept quiet [kep 'kwart], helped me ['hetp mi], stopped speaking ['stpp 'spi:kın], changed colour

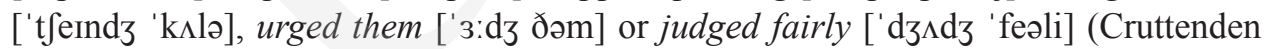
2008, 304).

In informal speech, the elision of only two-consonant clusters can be encountered, too, as in I want to [aI 'wpnə], He went away [hI 'wen ə'wer], Give me [gımI or Let me [lemI]. Interesting forms are also the informal gonna, gotta, and wanna, which stand for going to, have to (or 've got to), and want to (or want a), respectively. The elision also affects the $/ \mathrm{v} /$ in of in informal speech when it precedes a consonant, e.g. in lots of them ['lpts a 'ðem] or waste of money ['weIst a 'm^ni] (Roach 1998, 127).

In regional informal speech, $/ \mathrm{h} / \mathrm{can}$ be elided at the beginning of a word and the word then behaves as if it started with a vowel, namely it takes the an indefinite article or [ði] definite article, for instance an hill [ən' $\mathrm{t}]$ or the house [ði' aus]. Even among some RP speakers, one can find such words as historical, hotel, or hysterical realised without the initial $/ \mathrm{h} /$ and the grammatical result is the same, as in an historical novel [ənı'stb.rıkł 'nvvł]. Such realisation, however, is not common (Cruttenden 2008, 205).

Furthermore, whole unaccented syllables can also be omitted. If the same consonant appears again in the subsequent syllable, the first syllable of the pair is likely to be dropped. This can be observed in numerous words, such as library ['larb.II] or particularly [pə'trkjəli] (Skandera and Burleigh 2005, 96). 


\section{Research}

In this section, we are going to examine some fragments of genuine official English speech in terms of the reduction phenomena discussed above. The aim of the research is to look into the frequency of the reduction phenomena.

\subsection{Selection of the material and procedure}

I have decided to analyse approximately 20 minutes of data, consisting of three samples. The first sample, A short introduction to the Studio School (henceforth Studio School), is a speech by Geoff Mulgan on TED.com from 2011 about new, more practical, and less boring schooling. The second sample is a fragment of a BBC 4 podcast series In Touch about the cancellation of the DLA mobility component for disabled people living in residential houses. The last piece of the material, A History of the World in 100 Objects. Episode 8. Egyptian Painted Pottery Cattle from BBC Radio 4 (henceforth Pottery Cattle), is a fragment of a podcast series about clay statues of cattle in ancient Egypt.

Table 1. The data analysed

\begin{tabular}{|c|c|c|}
\hline Sample & Duration & Number of speakers \\
\hline Studio School & 5'54"' & 1 \\
\hline In Touch & $10^{\prime} 13^{\prime \prime}$ & 5 \\
\hline Pottery Cattle & $4^{\prime} 8^{\prime \prime}$ & 1 \\
\hline & $20^{\prime} 15^{\prime \prime}$ & 7 \\
\hline
\end{tabular}

Although In Touch is of longer duration and features more speakers than the other two samples, it conforms with the remaining ones, since each speaker talks individually and undisturbed by the others, and only rare interaction between the speakers is observed.

The audio material was downloaded together with transcripts from the source websites. Then the recordings were slowed down and listened to, with the instances of relevant phonetic phenomena being marked on the transcripts.

\subsection{Hypotheses}

The occurrence of the reduction phenomena is dependent not only on phonetic and phonological features, but also on individual preferences of a speaker, as well as his or her speech tempo or regional origin. Nonetheless, we managed to find samples produced by speakers who use the standard variety of British English. Thus, two hypotheses may be forged.

Firstly, if the samples are not scripted, the number of the reduction phenomena is noticeably higher. Thus, Studio School is expected to show a significant number of the phenomena, while Pottery Cattle barely any. In Touch was labelled as semi-scripted, 
since three of the speakers are journalists but the remaining two are not. Therefore, the number of reduction phenomena in In Touch should be somewhere between Studio School and Pottery Cattle.

Secondly, the sounds that are most frequently reduced are stops. Here, apart from $/ \mathrm{p} /, / \mathrm{b} /, / \mathrm{t} /, / \mathrm{d} /, / \mathrm{k} /, / \mathrm{g} /$, affricates $/ \mathrm{t} / /$ and $/ \mathrm{d} 3 /$ are considered as well, since they also contain a stop element. In order to check this, we kept thorough records of the numbers of reduction phenomena and calculated the percentages.

The results obtained are collated in tables, each dedicated to one sample.

\subsection{Studio School}

Studio School is a monologue, similar to a very short lecture, delivered in front of an audience. Because of that, it was labelled as unscripted. The reduction phenomena which occurred in the text are listed in Table 2 below.

Table 2. Reduction in Studio School ${ }^{5678}$

\begin{tabular}{|c|c|c|c|}
\hline Time & Fragment & Transcription & Phenomenon \\
\hline $19 "$ & I want to talk & [aI 'wbnə 'to:k] & $\begin{array}{l}\text { apocope of } / t /, \text { aphaeresis of } \\
/ \mathrm{t} /{ }^{5}\end{array}$ \\
\hline $25 "$ & of our conventional & [əv a: kən'ven $\left.{ }^{2} n \nmid t\right]$ & $\begin{array}{l}\text { syncope (triphthong } \\
\text { smoothing) }\end{array}$ \\
\hline $29 "$ & And it might just be & [ən It 'mai dzムs bi] & apocope of /t/ twice \\
\hline $49 "$ & we asked what was & [wi 'a:s wot wəz] & apocope of $/ \mathrm{kt} /$ \\
\hline $50 "$ & important need for & [Im'po:tən 'ni:d fə.I] & apocope of $/ \mathrm{t} /$ \\
\hline $55 "$ & we felt the most & [wi 'fet 'ðə məust Im' $\mathrm{p}$ & apocope of $/ \mathrm{t} /$ \\
\hline $56 "$ & important priority & рıаı'pıəti] & \\
\hline 1'1" & who just didn't like school & [hu dzus didn 'lark' 'sku:ł] & apocope of $/ \mathrm{t} /$, weakening ${ }^{6}$ of $/ \mathrm{k} /$ \\
\hline $1 ' 7 '$ & who kept complaining & [hu 'kep kəm' pleını]] & apocope of $/ \mathrm{t} /$ \\
\hline 1'14"' & we try to ask what & [wi 'tuar tu 'a:s wot] & apocope of $/ \mathrm{k} /$ \\
\hline 1'43”' & simple answer in a way & ['simpl 'a:ns. In ə 'weI] & syncope of /a/ \\
\hline 2'15" & practical projects & ['pıæktıkł 'p.odzekt's] & weakening of $/ \mathrm{t} /$ \\
\hline 2’21”' & who would have & [?u wəd 'hæv] & aphaeresis of $/ \mathrm{h} /$ \\
\hline 2’33” & no extra cost, no selection & 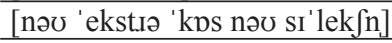 & apocope of $/ \mathrm{t} /$ \\
\hline 2’47”' & learn best by doing & ['la:n 'bes bai 'du:In] & apocope of $/ \mathrm{t} /{ }^{7}$ \\
\hline 3’07”' & famous for its airport & ['fermos fə? its 'eəpo:t] & reduction of $/ \mathrm{r} /$ to $/ \mathrm{?} /{ }^{8}$ \\
\hline
\end{tabular}

5 This results in a substandard, informal form, which is sometimes spelt wanna. The same form appears in 5' $43^{\prime \prime}$ in they want to get. On the other hand, a few words earlier, the full form ['wpnt to] is pronounced in They want to do things.

6 Weakening used in the table stands for no audible release of a stop. However, the records below the table, used for statistics, include both unreleased plosion and reduction to / $/$.

7 The same occurs in 2' 52 ' in the repeated phrase. However, in 2' 50 ', in the phrase learn best in teams, the speaker uses the full form: ['l3:n 'best in 'ti:mz].

8 The reduction here appears although the glottal stop most often substitutes the intrusive, not the linking $/ \mathrm{r} /$, as in the example above. A bit later, in 3'11" in the phrase famous for its beaches, the speaker uses the linking /r/: ['ferməs fə. Its 'bi:tfrz]. 
Pobrane z czasopisma New Horizons in English Studies http://newhorizons.umcs.pl

Data: 26/04/2023 11:12:32

On Reduction in English: What the English Don't Say

\begin{tabular}{|c|c|c|c|}
\hline 3'13"' & quite a lot of things & [kwait ə 'lo? ə 'Oryz] & $\begin{array}{l}\text { reduction of } / \mathrm{t} / \text { to } / \mathrm{P} /{ }^{9} \\
\text { apocope of } / \mathrm{v} /\end{array}$ \\
\hline $3 ’ 23$ ' & And perhaps most & [ən $\mathrm{p}^{\mathrm{h}}{ }_{\text {'.jæp m məひst] }}$ & syncope of $/ \mathrm{a} /$ and $/ \mathrm{h} /{ }^{10}$ \\
\hline $3{ }^{\prime} 28^{\prime \prime}$ & these field trials & ['ði:z 'fi:t 'traıəłz] & apocope of /d/ \\
\hline 3’31'” & lowest performing groups & ['ləuıIs pa'fo:min 'gru:ps] & apocope of $/ \mathrm{t} /$ \\
\hline 3’33” & jumped right to the top & ['dz^mp 'saI tðə 'top] & $\begin{array}{l}\text { apocope of /t/ twice, apocope } \\
\text { of } / \mathrm{a} /\end{array}$ \\
\hline 3’44”' & influenced some people & ['Influəns sm 'pi:pł] & apocope of $/ \mathrm{t} /$ \\
\hline 3'50”' & described himself as & [dis'kıarbd Im'setf 'æz] & aphaeresis of $/ \mathrm{h} /$ \\
\hline $45^{\prime \prime}$ & helping it work, not just & ['helpın I? 'w3:? not dz 4 st] & reduction of $/ \mathrm{k} /$ to $/ \mathrm{?} /$ \\
\hline 5'9"' & in fact, my nephew & [In 'fæ? mai 'nefju:] & reduction of $/ \mathrm{kt} /$ to $/ \mathrm{l} /$ \\
\hline 5'24”' & It's not perfect yet & [its np? 'p3:fək 'je?] & apocope of $/ \mathrm{t} /$ \\
\hline 6'1" & which is present, not as & [wit $\int \mathrm{IZ}$ 'p.ezn not əz] & apocope of $/ \mathrm{t} /$ \\
\hline 6’2"' & answer for every child & ['a:ns fə '?evıi 'tfartd] & $\begin{array}{l}\text { apocope of } / \mathrm{\partial} / \text {, reduction of } \\
\mathrm{r} / \text { to } / \mathrm{P} /{ }^{11}\end{array}$ \\
\hline 6’4"' & at least for an answer & [ə? 'li:s fə. ən 'a:nsə] & apocope of $/ \mathrm{t} / \mathrm{I}^{12}$ \\
\hline 6’10" & make that happen & ['meı? 'ðæ? 'hæpn] & reduction of $/ \mathrm{k} /$ to $/ \mathrm{R} /$ \\
\hline
\end{tabular}

Some of the examples in Table 2 require a comment. First of all, we have observed the speaker's general tendency to substitute a /t/ preceding a consonant with a $/ 2 /$. We have found a number of instances in such words as:9101112

- important - important priority [Im' po:?n p.ai' p.əti] (56") and most important of all (3'23'); ${ }^{13}$

- importance - the importance of [ði Im'po:?ñs əv] (1'32");

- animate - animate them ['ænımeI? ðəm] (5'35');

- that (both strong and weak forms) - complaining that the kids [kəm'pleını ðə? ðə 'kIdz] (1'7'), ideas that large numbers [aı' dıəz ðə? 'la:d3 'n^mbəz] (2'45"), that was a nice idea ['ðæ? wəz ə 'nars ar' dı] (2'59'), that influenced some people ['ðæ? 'Influəns sm 'pi:pł] (3'44') and make that happen ['mer? 'ðæ? 'hæpn] (6'10");

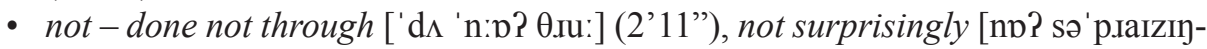
li] (3'42"), not perfect [no? 'p3:fak] (5'24') and They're not like all [ðeə 'nD? lark 'o:t] (5'35');

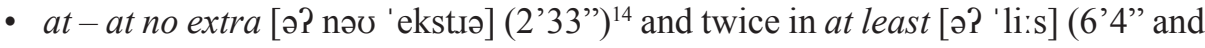
6'9");

9 What follows, however, is a vowel.

${ }_{10}$ In this case, aspiration of $/ \mathrm{p} /$ in an unstressed syllable and appearance of /r/ occur as compensatory phenomena for the elision.

11 Notice that two seconds later (6'4"), in the phrase for an answer for some children, the speaker uses both linking /r/ in for an and /o/ in answer, in contrast to the preceding phrase with a similar wording. The form [a:ns] also appears earlier, in 1'43", with linking /r/ following.

${ }^{12}$ At least is again reduced to [ə? 'li:s] in 6'9" in the phrase at least can help us.

13 In 1'38", however, the speaker uses the full form [Im'po:tnt].

14 Interestingly, in 4'58", in the phrase right at the heart, we observe no elision: ['.tait ət də 'ha:t]. 


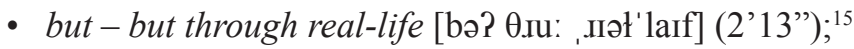

- it - helping it work ['hełpın I? 'w3:?] (4'5");

- yet-not perfect yet;

- but [np? 'pз:fək 'je? bət] (5'24'), and out - you out there [ju 'av? 'ðeə] (5'50").

Furthermore, the speaker tended to drop the final $/ \mathrm{t} /$ in negated contractions, as in didn't-didn't like [didn 'lark'] (1'1'), didn't have [drdn 'hæv] (1'11') or in doesn't It doesn't animate [it $\mathrm{d} \Lambda \mathrm{zn}$ ' $æ n$ mer?] (5'35"). Therefore, these instances will not be counted in the percentage result of reduced words in this sample and have not been included in the table.

With regard to this, the percentage result of reduction is $3.81 \%$ (1,050 words in total, 40 reduced $^{16}$ ). The recording gave us 4 examples of syncope, 27 of apocope, 4 of aphaeresis, 9 of weakening. The total number of reduction processes is 44 . Stops were reduced in 33 cases $(75 \%)$ and 26 of them were /t/, vowels in 5 cases and other consonants in 6 . The results are presented in Table 3 .

Table 3. Reduction in Studio School (unscripted)

\begin{tabular}{|c|c|c|c|c|}
\hline Wor & al & Nords reduc & \multicolumn{2}{|c|}{ Reduction percentage } \\
\hline \multicolumn{2}{|c|}{1,050} & \multicolumn{2}{|l|}{40} & \\
\hline \multicolumn{5}{|c|}{ T I O N P R O C E S E S } \\
\hline In total & Syncope & Apocope & Aphaeresis & Weakening \\
\hline \multirow[t]{4}{*}{44} & 4 & 27 & 4 & 9 \\
\hline & & DUN D S & E C T E D & \\
\hline & Stops in general & $/ \mathrm{t} /$ & Other consonants & Vowels \\
\hline & 33 & 26 & 6 & 5 \\
\hline
\end{tabular}

\subsection{In Touch}

In In Touch, there are five speakers altogether: two men, who are professional radio journalists, and three women, one of whom is also a professional radio broadcaster; the two remaining speakers are not trained for professional recording - they are people to whom the topic of the programme (the cancellation of the DLA mobility component) applies. They are not guests in the studio so the sample cannot be considered a discussion. Each answer to the journalist's questions is given in an elaborate way (at least a few sentences), which is why this fragment has been chosen for the study. The recording has been classified as semi-scripted. Table 4 presents the reduction phenomena found in the recording.

\footnotetext{
15 In the phrase but independently run, the speaker does not use the glottal stop: [bət Indi' pendntli 'rAn].

16 By reduced words we understand words in which at least one sound was affected by reduction.
} 
Table 4. Reduction in In Touch

\begin{tabular}{|c|c|c|c|}
\hline Time & Fragment & Transcription & Phenomenon \\
\hline 5'25" & I asked her & [ai 'a:sk hə] & apocope of $/ \mathrm{t} /{ }^{17}$ \\
\hline 5'34" & deafblind people & ['defblain 'pi:pl] & apocope of $/ \mathrm{d} /{ }^{18}$ \\
\hline $5,56 "$ & be hit by this & [br 'hi? bai 'ðıs] & reduction of /t/ to / $/$ / \\
\hline 6 ' & the moment from the & [ðə 'məひmən f.əm ðə] & apocope of $/ \mathrm{t} /$ \\
\hline 6'14"' & authority expects to take & [0: 'Ob.riti rk'speks to 'terk] & syncope of $/ \mathrm{t} /$ \\
\hline 6'31" & travel independently of & ['trævł Indi' pend²nli əv] & syncope of $/ \mathrm{t} /{ }^{19}$ \\
\hline 6'54" & the government says & 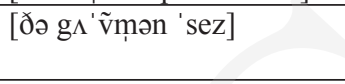 & $\begin{array}{l}\text { syncope of } / \mathrm{n} / \text {, apocope of } \\
/ \mathrm{t} /{ }^{20}\end{array}$ \\
\hline 7’24”' & supposed to be & [so'pouz to bi] & apocope of /d/ \\
\hline 7'24'” & earmarked for exactly the & ['rəma:k fəı Ig' zækli ðə] & apocope and syncope of / $/ \mathrm{t}$ \\
\hline 7'44'” & to prevent cuts to other & 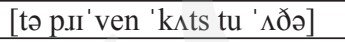 & apocope of $/ \mathrm{t} /$ \\
\hline 8'1" & And amongst the groups & [ənd ə'mpyz ðə 'gru:ps] & apocope of /t/ and voicing \\
\hline 8'22”' & Liz herself lives & ['liz o'self 'livz] & aphaeresis of $/ \mathrm{h} /$ \\
\hline 8'24'” & she explained what the & [ 1 i ik'splein wpt ðə] & apocope of /d/ \\
\hline 8'41"' & have a support worker & ['hæv ə sə'po: 'wз:kə] & apocope of $/ \mathrm{t} / 21$ \\
\hline 9'8" & have to find myself & ['hæv tə 'fain mai'self] & apocope of $/ \mathrm{d} / 22$ \\
\hline 9'10"' & quite considerable & [kwait kən'sıd.ıəłł] & syncope of /a/ \\
\hline 9'24”' & other disabled people & 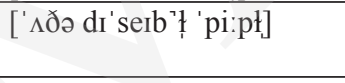 & $\begin{array}{l}\text { apocope of } / \mathrm{d} / \text {, weakening } \\
\text { of } / \mathrm{b} / \text { /3 }^{3}\end{array}$ \\
\hline 10'10" & at worst not going to & [ə? 'w3:s np? 'gəvin to] & apocope of $/ \mathrm{t} /$ \\
\hline $10^{\prime} 45^{\prime \prime}$ & It's difficult to believe & [Its 'dıfikt, to bi'li:v] & apocope of $/ \mathrm{t} /$ \\
\hline 10’54”' & I suspect that they & [aI sə'spek ðə? ðеI] & apocope of $/ \mathrm{t} /$ \\
\hline 11'12" & we asked the Department & [wi 'a:sk ðə dı'pa:tmənt] & apocope of $/ \mathrm{t} /$ \\
\hline 11'24”' & to help tackle the & [tə 'hełp' 'tækł бə] & weakening of $/ \mathrm{p} /$ \\
\hline 11’36" & it designed to support & [It di'zain tə sə'po:t] & apocope of $/ \mathrm{d} /{ }^{24}$ \\
\hline $11^{\prime} 47^{\prime \prime}$ & authority contracts with & [0:'Op.ıti 'kpntræks wıð] & syncope of /t/ \\
\hline 11'52" & residents assessed needs & ['rezidənts ə'ses 'ni:dz] & apocope of $/ \mathrm{t} /$ \\
\hline 12 '4” & Our commitment to & [avə kə'mitmən tə] & apocope of $/ \mathrm{t} /$ \\
\hline 12’24”' & to protect the people & [tə pro'tek ðə 'pi:pł] & apocope of $/ \mathrm{t} /$ \\
\hline $12 ’ 38^{\prime \prime}$ & Eric Westbrook & ['e.ık 'wesb.uu:k] & syncope of $/ \mathrm{t} /$ \\
\hline $13 ’ 39 ”$ & $\begin{array}{l}\text { website because essen- } \\
\text { tially }\end{array}$ & ['websaIt kəz I'sen $\left.{ }^{\jmath} l i\right]$ & fore-clipping \\
\hline
\end{tabular}

17 However, in 12'54" in the phrase I asked him, there is no apocope but aphaeresis in the weak form: [ai 'a:skt Im].

18 The same happens in 5'43" and 5'51" (the same speaker), 9'23", 9'42", 9'43", 10'52", 11'17", in the phrase blind people in 12'56" and 13'44", blind games in 13'53" and blind person in 15'22" (different speakers).

19 The same form appears in 8'23"' and 8'34" (each in a different speaker).

20 The same speaker in the next phrase (7') says but the government has been talking with the synco-

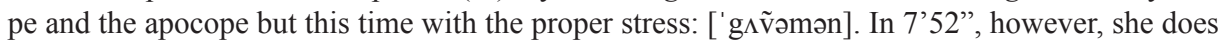
not use the syncope. This also occurs in different speakers' speech, as in The government keep talking in 10'14" and in the government would want in 10'46".

21 The speaker uses the same form in 8'46" and 8' $58^{\prime \prime}$.

22 The same occurs in the phrase eventually find one in 14'55".

23 The same form appears in 11'12', 11'37', and 12'9', but without the weakening.

24 The same form occurs in 11'49' and in $12^{\prime} 51^{\prime \prime}$ in the phrase designed for people. 
Pobrane z czasopisma New Horizons in English Studies http://newhorizons.umcs.pl

Data: 26/04/2023 11:12:32

34

Maciej Tomaka

\begin{tabular}{|c|c|c|c|}
\hline $13^{\prime} 46^{\prime \prime}$ & Ian runs software & ['aiən 'rınz 'spfweə] & syncope of $/ t^{25}$ \\
\hline $13 ' 57^{\prime \prime}$ & the last one was & [ðə 'la:s wın wəz] & apocope of /t/ \\
\hline $14^{\prime} 23^{\prime \prime}$ & with its spoken clues & [wıð I? 'spəokn, 'klu:z] & apocope of /s/ \\
\hline $14{ }^{\prime} 41^{\prime \prime}$ & which are called words & [wit $\int$ ə 'ko:ł 'w3:dz] & apocope of /d/ \\
\hline $15,5 "$ & extensive help file that & [Ik'stensıv 'help' 'faił ðə?] & weakening of $/ \mathrm{p} /$ \\
\hline $15^{\prime} 8^{\prime \prime}$ & recommend to start & [,rekə'men to 'sta:t] & apocope of /d/ \\
\hline $15^{\prime} 29 \prime$ & people who have never & ['pi:pł hu əv 'nevə] & aphaeresis of $/ \mathrm{h} /$ \\
\hline $15^{\prime} 31$ ”' & would like to try & [wod 'lais to 'tuar] & reduction of $/ \mathrm{k} /$ to $/ \mathrm{P} /$ \\
\hline
\end{tabular}

Moreover, all of the speakers showed a strong tendency to substitute the final /t/ with $/ \mathrm{R} /$, not only in pronouns or prepositions, but also in lexical words. Furthermore, they also tended to drop the final /t/ from negative contracted forms. Hence, these instances have been considered as a general inclination and have not been counted as reduction.

Having said this, we may state that 65 words out of 1,775 were reduced, which amounts to $3.66 \%$. There were 68 reduction processes, 47 (69.12\%) of which were examples of apocope, $12(17.64 \%)$ of syncope and $3(4.41 \%)$ of aphaeresis, $5(7.35 \%)$ of weakening and $1(1.47 \%)$ of clipping. In total, stops were elided in 61 cases $(89.7 \%)$, vowels in just 2 cases and other consonants in $6{ }^{26}$ Among stops, /t/ was reduced 25 times. These results are presented in Table 5 .

Table 5. Reduction in In Touch (semi-scripted)

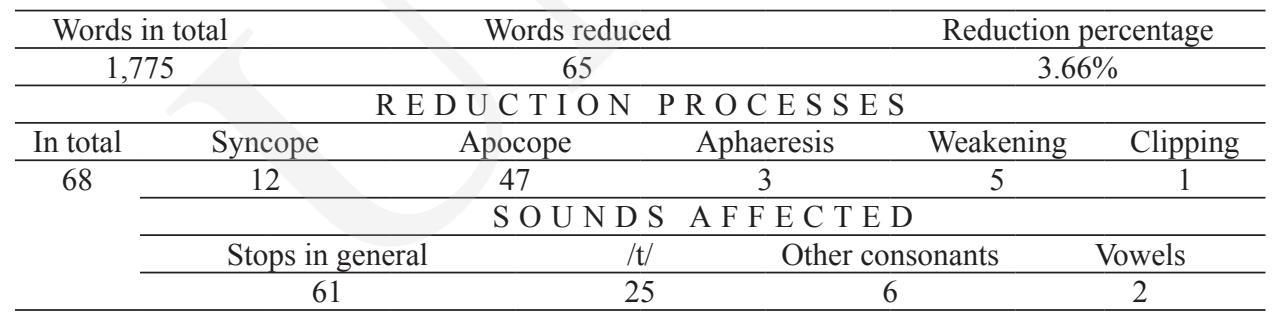

\subsection{Pottery Cattle}

Pottery Cattle comes from one speaker, with the exception of two very short sentences, which are quotes from two professors who contributed to the story, one sentence each. This material was professionally recorded in a studio by a man who, as we assume, had familiarised himself with the text of the speech and prepared for the recording - therefore, it was labelled as scripted. The speaker's pronunciation is much more accurate and clear than in the previous samples. Hence, very few reduction instances have been found. They are presented in Table 6 .

25 The word appears twice close to each other: "Ian runs software calles Spoonbill software".

26 The difference in numbers between reduction processes and sounds affected results from the fact that clipping was counted as one process, but it affected two sounds: /b/, which is a stop, and /I/, which is a vowel. 
Pobrane z czasopisma New Horizons in English Studies http://newhorizons.umcs.pl Data: 26/04/2023 11:12:32

On Reduction in English: What the English Don't Say

Table 6. Reduction in Pottery Cattle

\begin{tabular}{|c|c|c|c|}
\hline Time & Fragment & Transcription & Phenomenon \\
\hline $13 "$ & see ourselves entering & ['si: avə' selvz 'ent.ıIy] & syncope of /a/ \\
\hline $15 "$ & discovering the hidden & [dI'skıvıIn ðə 'hIdn] & syncope of /a/ \\
\hline 19" & rewriting history & [.ı'.Jartıy 'hist.ıi] & syncope of /a/ \\
\hline $22 "$ & should be warned that & [Јəd bi 'wə:n ðət] & apocope of /d/ \\
\hline $36 "$ & almost clerical dryness & ['o:łməus 'kle.ıkł 'dıanəs] & apocope of $/ \mathrm{t} /$ \\
\hline 2’49”' & they've been grazing & [ðәv bin 'greızın] & reduction of $/ \mathrm{eI} /$ to $/ \mathrm{a} /$ \\
\hline
\end{tabular}

There are 451 words in this fragment, 6 of which were reduced, that is $1.33 \%$. There were 6 reduction processes altogether, 4 of syncope and 2 of apocope. Stops were elided only in 2 cases (33.33\%), whilst the remaining 4 cases concerned vowels $(66.66 \%)$. Table 7 presents the exact results.

Table 7. Reduction in Pottery Cattle (scripted)

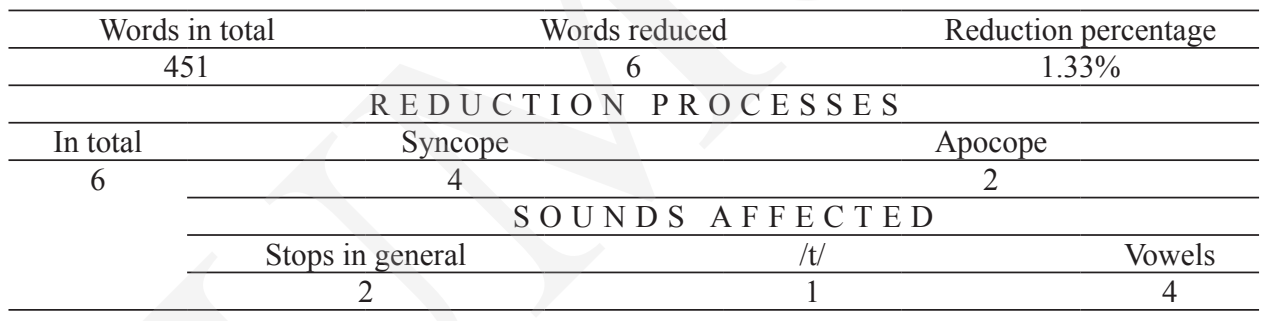

\section{Results}

Having demonstrated all the results from our research, we will now refer to the hypotheses we put forward in 2.1 .

According to the first hypothesis, the number of reduction phenomena would be smaller in a scripted sample, larger in a semi-scripted one, and the largest in unscripted. That is why we kept thorough statistics of the reduction. The results support our hypothesis, as can be seen in Table 8 .

Table 8. Percentage of reduction in the audio material

\begin{tabular}{|c|c|c|}
\hline Sample & Percentage of reduction & Type of speech \\
\hline Studio School & $3.81 \%$ & unscripted \\
\hline In Touch & $3.66 \%$ & semi-scripted \\
\hline Pottery Cattle & $1.33 \%$ & scripted \\
\hline
\end{tabular}

The difference between Studio School and In Touch is, however, minute: 0.15\%. Nonetheless, looking at this table, one must bear in mind the other differences between Studio School and In Touch: they differ in duration (5'54" vs. 10'13"), in the number of words $(1,050$ vs. 1,775), and in the category of speech they represent (a monologue 
in front of an audience and a prepared radio programme with journalists and guest speakers).

It seems that our findings favour the second hypothesis as well. In the material, there were 119 elements reduced altogether, 96 of which were stops, which gives the result of $80.67 \%$. The remaining elements were: vowels $-11(9.24 \%)$, fricatives -8 $(6.72 \%)$, and other consonants $-4(3.36 \%)$.

The frequency of occurrence of reduction in the whole material is $3.39 \%$ (that is, 111 words reduced out of the total of 3,276). Table 9 presents the detailed data.

Table 9. The whole empirical material

\begin{tabular}{|c|c|c|c|c|c|}
\hline \multicolumn{2}{|c|}{ Words in total } & \multicolumn{2}{c|}{ Words reduced } & \multicolumn{2}{c|}{ Percentage } \\
\hline \multicolumn{2}{|c|}{3,276} & \multicolumn{2}{c|}{111} & \multicolumn{2}{c|}{$39 \%$} \\
\hline \multicolumn{7}{|c|}{ R E D U C T I O N R O C E S S E S } \\
\hline In total & Syncope & Apocope & Aphaeresis & Weakening & Clipping \\
\hline 119 & 20 & 77 & 7 & 14 & 1 \\
\hline \multicolumn{7}{|c|}{ S O U N D S } & A F F E C T E D & Other \\
\hline In total & $\begin{array}{c}\text { Stops in } \\
\text { general }\end{array}$ & t/ & Vowels & Fricatives & 4 \\
\hline 119 & 96 & 52 & 11 & 8 & $3.36 \%$ \\
\hline
\end{tabular}

\section{Conclusion}

The research shows that prior preparation and speaking with the aid of a script influence the occurrence of elision. The audio material has provided us with a straightforward answer, although one must bear in mind the differences between the samples analysed.

Furthermore, stops proved to be the most frequently elided elements in the audio material: they constituted more than $80 \%$ of the elements reduced. Amongst all the stops elided, the most significant number falls on $/ \mathrm{t} /$, which constituted $54 \%$ of them. This means that $/ \mathrm{t} / \mathrm{alone}$ constituted more than $40 \%$ of all the elements affected by reduction. Furthermore, final / $t /$ was reduced in 43 cases, which is more than a third of all the sounds reduced. The second most frequently elided elements were vowels, but they amounted to less than a tenth of the total.

Another conclusion which may be drawn from the analysis of the audio material is that in present-day colloquial English, there is a strong tendency to use [?] in the place of final $/ \mathrm{t} /$ before a vowel. Another easily observed tendency is an omission of the final $/ \mathrm{t} /$ of the negative contracted forms, so that $-n{ }^{\prime} t$, normally pronounced as [nt], is realised as $[\mathrm{n}]$.

This study has shown that phonetic reduction is a topic worth studying, since it affects native speakers' pronunciation to a noticeable extent. The analysis has confirmed that earlier preparation for speaking influences the pronunciation, namely there 
are fewer reduction phenomena. The present paper can be beneficial in teaching not only of pronunciation but also of listening skills. It may help teachers provide explanations and choose proper materials for classwork (semi- or unscripted samples, rather than recorded in a studio). This may also be an inspiration for new research, such as looking into students' listening comprehension of various speeches: official, informal, colloquial, or scripted, semi-scripted, unscripted. The type of communicative situation seems to be worth considering, too, e.g. a public and official speech (for instance, given by a politician), a presentation in front of an audience, a presentation recorded in order to be listened to and without an audience present, a recorded podcast, a video, TV or radio news, TV or radio programmes (interviews, reports, phone calls from listeners or viewers).

\section{References}

Cruttenden, Alan. 2008. Gimson's Pronunciation of English. London: Hodder Education.

Crystal, David. 2008. A Dictionary of Linguistics and Phonetics. Malden, MA - Oxford, UK Victoria, Australia - Singapore: Blackwell Publishing.

Reszkiewicz, Alfred. 1981. Correct Your English Pronunciation. Warszawa: PWN.

Roach, Peter. 1998. English Phonetics and Phonology. A Practical Course. Cambridge: Cambridge University Press.

Skandera, Paul, and Peter Burleigh. 2005. A Manual of English Phonetics and Phonology. Twelve Lessons with an Integrated Course in Phonetic Transcription. Tübingen: Gunter Narr Verlag.

\section{Research material}

BBC Radio 4: A History of the World in 100 Objects. Episode 8 - Egyptian model of clay cattle. http://downloads.bbc.co.uk/podcasts/radio4/ahow/ahow_20100127-1000a.mp3 (8"-2'9", 2'42"-3'50") [accessed 25.05.2015]

BBC Radio 4: In Touch - The future of DLA. http://www.bbc.co.uk/programmes/b00vrvx1 (5'43"-15'54") [accessed 25.05.2015]

TED.com: Geoff Mulgan - A short intro to the Studio School. http://download.ted.com/talks/ GeoffMulgan_2011G.mp3?apikey=489b859150fc58263f17110eeb44ed5fba4a3b22 [accessed 25.05.2015] 